\title{
Using Wattpad to Promote the Students' Responses to Literary Works: EFL College Students' Perspectives and Experiences of Enjoying Short Stories
}

\author{
Mega Anggitasari \\ Universitas Galuh \\ meganggitasari@gmail.com \\ Wawan Tarwana \\ Universitas Galuh \\ wtarwana@gmail.com \\ R. Bunga Febriani \\ Universitas Galuh \\ bunga.febriani@gmail.com \\ Syafryadin \\ University of Bengkulu \\ syafryadin@unib.ac.id
}

\begin{abstract}
This research is to investigate how EFL college students response in enjoying short stories by using Wattpad and to find out how their perception and experiences in enjoying short stories by means reading Wattpad. As interest in literacy activities, EFL college students' choose Wattpad as an application to read short stories, Wattpad is a fairly popular and efficient application for reading short stories and can provide comments directly within the short story paragraphs and Wattpad has many advantages in promoting reader-response theory to EFL college students' .This case study was conducted to the college students and 40 students. Three instruments covering the observation, the interview, and the questionnaire were chosen to gain the data. It was concluded that there is the positive feedback of using Wattpad as a media to learning literature similar to those previous studies, this research also focuses on Wattpad as a media to learning literature.
\end{abstract}

Keywords: Wattpad, EFL colleges's students, Literature

\section{A. Introduction}

Literature is a written work that divided into fiction or non-fiction, and whether it is poetry or prose. Short story is one of them. Short Story is a brief fictional prose narrative that is shorter than a novel and that usually deals with only a few characters. The short story is usually concerned with a single effect conveyed in only one or a few significant episodes or scenes (Hansen, 2019; Febriani, et al. 2020). The generic structure of a short story is conflict, climax and resolution. Literature as a tool that can foster communication and introduce learners to such discourse types as the expressive (e.g. letters), the transactional (e.g. advertising), and the poetic (i.e.) (Al-mahrooqi, 2012). Literature also can be a tool for communication.Technology becomes a tool that is very necessary for the Teaching and Learning Process. Web-based educational methods have become one of the more popular 
areas of focus with broad reach across large distances and availability 24/7. (Luo et al., 2020). It is easier for the teacher to teach their student while using technology. Also in this modern era a lot of students using gadgets as a media for learning.

Teaching literary works at the level of education across countries has imposed the use of technology. It is found that technology integration as stated by Gilakjani (2017) \& Handayani, et al. (2020) allow teachers to be more creative and more effective in their teaching and motivates learners to be engaged in classroom activities. In other words, teaching literature with using technology or web-based educational methods is a more effective and motivated student to be aware of their literacy skills both reading and writing through different kinds of materials. Nowadays, there are many platforms on the internet that provide sites for free reading. According to Kowalczyk, (2019). Websites that contain different e-books that can be accessed and downloaded for free such as Wattpad (wattpad.com), Electric Literature (electricliterature.com), The New Yorker (thenewyorker.com), Project Gutenberg (gutenberg.org), Fictionaut (fictionaut.com), 3 AM Magazine (3ammagazine.com), and Inkitt (inkitt.com). One of them is Wattpad. Wattpad is a social media platform which authorizes its users to write stories which can be accessed and managed easily even for a completely new writer. Wattpad (Safitri \& Sukmawati, 2018). Wattpad becomes a most popular application to read a novel also Wattpad can help students to be more aware of their literary skill.

As interest in literacy activities, EFL college students' choose Wattpad as an application to read short stories, Wattpad is a fairly popular and efficient application for reading short stories and can provide comments directly within the short story paragraphs and Wattpad has many advantages in promoting reader-response theory to EFL college students' ((Davies, 2017).

There are so many studies that use Wattpad as a media to learning literature. Rahman \&Iwan, (2019) found that the Wattpad platform can be used to publish literary works students in the form of prose to further obtain constructive peer to peer feedback. Similar to Rahman and Iwan. (Sari, 2016) found that students were more interested in using the media and actively giving comments and express their feelings or ideas after reading the story. It means Wattpad can help students in learning literary. Then same as (Bal, 2018) argue that Wattpad was considered a venue where participants can express themselves comfortably.

However, in the previous study, the researchers just found that Wattpad can be a platform for sharing short stories and giving peer feedback to the author after reading a story. Therefore, the researcher would like to find out How EFL college students response in enjoying short stories by using Wattpad and to find out how their perception and experiences in enjoying short stories by means reading Wattpad. Wattpad was founded by Allen Lau and Ivan Yuen in 2006. It is an application developed for online reading writing (Reid, 2016). Wattpad offers a free digital environment, feedback, and an experimental environment for new and even experienced writers (Bold, 2018). Wattpad also offers reading opportunities and innovations; for example, it features readers' views on the chapters of a book and suggestions for new sections of texts (Sari, 2016). Wattpad is allowed to join and offers its individuals a computerized stage for both perusing and composing. In spite of the fact that it offers traditionally distributed works that are out of copyright, Wattpad clients primarily peruse and add to stories composed by different users. It also allows users to read and write texts in different contexts. It features a wide range of genres, including action, general fiction, paranormal, mystery/thriller, spiritual, horror, werewolves, fantasy, humour, young chick-lit, romance, classics, vampires, science fiction, adventure, teenage fiction, random, fanfiction, historical fiction, and nonfiction. Wattpad's aim, similar to that of Facebook, YouTube and 
others, is to facilitate the creation of content in order for that content to generate interactions between users and so build a community (Davies, 2017). Wattpad is one of kind social media functioned to reading, writing and sharing a story.

Based on the background of the study, the research questions that the writer formulates are as follows: (1) How are EFL college students' response in enjoying short stories by using Wattpad?; (2) How do the students perceive the use of Wattpad in reading short stories?); and (3) What are EFL College Students' experiences in enjoying short stories using Wattpad?. Meanwhile, the purposes of this research are: (1) To find out how EFL college students' response in enjoying short stories by using Wattpad; (2) To find out of students' perception on the use of Wattpad in reading short stories; (3)To find out experiences of EFL College Students' in enjoying short stories by means reading Wattpad.

\section{B. Methodology}

In this research, the researcher conducted a qualitative case study method. According to Creswell (2013), a case study method where the researcher explores in depth a program, an event, an activity, a process, or one or more individuals. In this study was carried out the detailed description of the case. Yazan (2015) stated that despite being one of the most frequently used qualitative research methodologies in educational research. In this case, the researcher chooses a case study as a research design. The present study was conducted to analyze the perspectives and experiences of EFL college students' while reading a short story in Wattpad. The previous section emphasizes the need for EFL college students to focus on their perspective and experiences while reading a short story in Wattpad. To be able to talk about their perspectives and experiences.

To collect the data, the researcher did the following research procedures. Firstly,the researcher analysed the data from observations. The data from observation analysed by describing, and exploring the data. In this study, there was one types of observation namely online observation. Then, the researcher analysing online observation from screenshot (chat) from comment section on Wattpad. After that, the researcher classified and described them to present data. Then, the researcher interpreted and gave a comment on the present data. Finally, the researcher concluded and verified the data qualitatively.

Secondly, the close-ended questionnaire consisted of fifteen statements with four item answers. The students' responses to the questionnaire were given a thick to the column of the appropriate statement based on their own experience and belief. The respondents of the questionnaire items were forty students. Lastly, the researcher took the student as the interviewee. The researcher use semi-structured interview to obtain the data of the study. Furthermore, the researcher conducted the interview in English language and it consisted of five questions. Moreover, the resercher conducted the interview in order to find out student's experience of the using Wattpad to reading short story. 


\section{Results and Discussion}

1. Results

After collecting the data from the research instruments, the writer conducted the analysis that was described as follows:

\section{How are EFL College Students in Enjoying Short Stories by Using Wattpad}

The observation was complete to answer the research question number one about "How EFL College students enjoy short stories by using Wattpad?" The observation was conducted four days. The researcher conducted the observation start on June 20th, 2020 and finished on June 24th, 2020, because the researcher must read a whole story. At the comment section on some short story in Wattpad.

Based on the data collected from e-observation, the data describe based on the comment section that readers give to the story. To describe and interpret the data, the researcher has the data resulted in some relevant theories which have been outlined in chapter II. Finally, the researcher conducted and verified the data.

This activity was proposed to find out EFL College students enjoy short stories by using Wattpad. In doing observation, the researcher using a mobile phone to screenshot some comment in Wattpad and observation sheet to get the valid data.

In analysing comment section on Wattpad, the researcher used form observation from Ningrum, C. H. (2018).

1. Interpretive/ Reflective

"They are really gud, and took strict. Sometimes when they scold me I feel like I am alone. But papa and amma, you are really loving bcoz I am lucky to be your child.... Miss u papa"

"Nice transitioning to introducing the main character"

"I just thought of Chris Hemswort"

"I don't know why but I'm picturing him as Matt Healy"

"Omg!! I'm picturing Gavin Leatherwood!! Omg my!!"

"Nah, we all know it will only start everything"

2. Affective

"I feel ya gurl, I feel ya"

"While reading these lines, I felt my heart fluttered and hundreds of butterflies summersaulted in my stomach"

"This doesn't sounds good"

"I'm so excited and nervous at the same time"

"Okay, creepy"

"I'm blushing and it's not even me"

"Yeah... I can feel it too"

\section{Interpretive or reflective response.}

A lot of students' could mention their personal beliefs that were brought back when they discussed some parts of the story and also they might reflect on their own experiences, attitudes, or knowledges. According to Rosenblatt as cited in Iskhak (2015), reader-response theory usually leads to the esthetic reading, in which it is the reading process that the readers play an active role to create meanings of the text by connecting their experience and emotional competence. In this case, the students' can relate the short stories to their real life. 


\section{Affective response.}

Some of the students' gave a response to the short story by expressing their feelings about it. Nunning (2017) stated that stories be able to broaden our emotional horizon and expand the range of emotions which we can identify and understand. They can enable readers to empathically share feelings they have not experienced or experienced in their own lives. So affective response is an emotion that the students' feels when reading a short story.

It can be concluded that a lot of students' could mention their personal beliefs that were brought back when they discussed some parts of the story and also they might reflect on their own experiences, attitudes, or knowledge it's called the interpretive response. Also, they can enable readers to empathically share feelings they have not experienced or experienced in their own lives. So affective response is an emotion that the students' feels when reading a short story it's called affective response.

\section{Students' Perception of the Use of Wattpad in Reading Short Stories.}

The data from close-ended questionnaire would explain to answer the second research question about students' perception of the Use of Wattpad in Reading Short Stories. The researcher managed the questionnaire on July $19^{\text {th }}, 2020$. The question consists of fifteen questions. The results of triangulation could reveal the students' perceive toward the Use of Wattpad in Reading Short Stories. Furthermore, the researcher described the questionnaire to find out the students' perception of the Use of Wattpad in Reading Short Stories. Besides, the results of the questionnaire were also correlated with the theories in the second chapter to strengthen the findings. In this regard, the results of the questionnaires' responses from the first until the fifteenth items were described in the following chart.

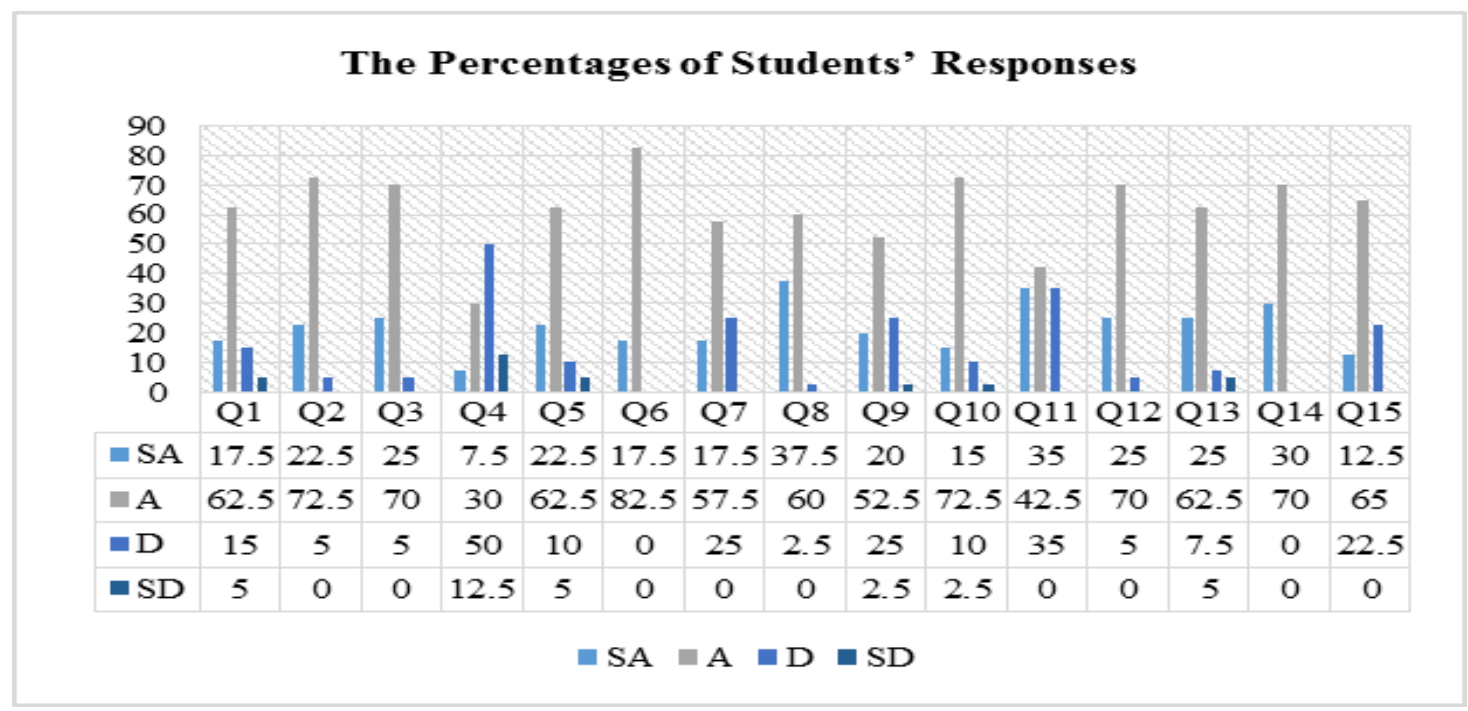

Picture 4.1. The Percentages of Students' Responses in Every Item

Based on picture 4.1, it was found that there was several students' perception on the use of Wattpad in reading short stories. They recognized that they a lot using Wattpad than using a book in reading a short story $(62.5 \%)$. They feel easy reading short story on Wattpad than a book $(72.5 \%)$. They realize that using Wattpad is fun to read short stories (70\%). But they 
would choose book than a Wattpad (50\%). The students' think that Wattpad is easier to read and access also cheaper to buy a short story (62.5\%). The students recognize that using Wattpad is really help them to read a short story (100\%). The students often using Wattpad to read short stories $(57.5 \%)$. The students enjoy reading a short story on Wattpad (60\%). They felt Wattpad can motivate them to improve their literacy skill $(52.5 \%)$. They recognize that after using Wattpad they can improve their vocabulary (72.5\%). The students think that not important to have Wattpad on their mobile phone (35\%). The students know that Wattpad is useful media to read a short story $(70 \%)$. The student thinks that on Wattpad they can easily response and comment on the short stories (62.5\%). The students can easily access Wattpad to read short stories whenever and wherever they are (100\%). the students' know Wattpad from their friend or family and the rest they know by themselves $(65 \%)$.

To summarize, the results of the questionnaire from the first to the fiftieth items had been analyzed and linked with the theories in the second chapter at answering the second research question. The results showed that the students gave their positive responses toward using Wattpad to promote the students' responses to literary works.

They perceived Wattpad that is easier to read short stories and they can learn about new vocabulary by reading a short story on Wattpad. And a lot of students knows that they can improve their literacy skill by reading a short story on Wattpad. As a result, every student can access Wattpad anywhere and every time. So the students have easier access to learn new things and Wattpad is a useful media to help the students increase their literacy skill and vocabulary.

\section{EFL College Students' Experiences in Enjoying Short Stories by Means Reading Wattpad}

The data from the semi-structured interview would explain to answer the third research question about students' experiences in enjoying short stories by means reading Wattpad. The researcher managed the questionnaire on July $15^{\text {th }}, 2020$. The question consists of five questions.

Question number one is "Do you know Wattpad? Do you read a short story on Wattpad? How would you compare reading a short story on Wattpad and printed book?" The student answered,

"Yes, I know Wattpad. Mmm.. ya, I read a short story on Wattpad. I think that... In comparison reading a short story on Wattpad and printed book I think, for the storyline or the generic structure is the same. And now is rarely people forget to bring their mobile phone. Also, Wattpad is more practical because we can read every time than we want without a carried book everywhere and we just scroll up to read short stories. Mmm... And I am more comfortable when I read a short story on Wattpad meanwhile I always feel sleepy when I read a short story on printed books"

Based on the students' answer on the first question, the result presented that the students' feel it easier and practical to read a short story because the students just open their mobile phone and didn't have to carry a book everywhere. According to Rahman (2019), Digital reading is reading the texts from the technological medium such as the cellphones, tablets, or computers either online or offline. Therefore, Wattpad is easier to access because Wattpad can support them to read short stories anywhere.

Furthermore, the student's answer on question number two is "Can Wattpad be a tool to learn literature? Is effective to use Wattpad as a media to increase someone literacy?" The student answered, 
"Yes because in Wattpad we can found a lot of type of text not only a short story. Yes, but depending on the plot, language style and writing style. Because a lot of author in Wattpad do some research before writing a story. So because of that, the readers would have new knowledge."

From the student's answer to the second question, the result showed that Wattpad can increase their literacy and can help them to learn literature. It can be concluded that literary work like short story helps the student focused on the story content, plot and language components (Tevdovska, 2016). Also, Rebora \& Pianzola (2018) stated wattpad is a very important resource for everybody interested in literature. In this case, Wattpad can help the students to learn about literature and can increase their literacy skill by reading a short story on Wattpad.

On the next question, the student's answer on question number three is, "Have you ever feel emotional when reading a short story? Give me a reason" The student answered,

"Of course, especially if the author can write such a good sad plot maybe I would cry. Also if the author describes some beautiful place that very detailed. I can imagine how beautiful it is and I feel happy if I found such a good story"

Based on the student's answer on the third question, the result showed that the students can have the same feeling with the story if the author can explaining or describing the situation well. According to Tirocchi (2018) Wattpad the platform offers a way to re-read, reinterpret and reinvent narrations, starting with existing and well-known materials. Finally, stories are a tool through which to share emotions and to connect with others. Wattpad is a place for us to share emotion and connect with others.

Question number four is "What is your favourite genre in Wattpad? Is easy to find your favourite genre in Wattpad?" The student's answered,

"My favourite genre is action and sci-fi, it's easy because we just click the tag of the genre and yah story about the genre showed, different from printed books because when we want to read a short story in a book we must read the synopsis first and it takes time"

From the student's answer, the result showed that the feel easy to find their favourite genre in Wattpad. Because Wattpad features a wide range of genres, including action, general fiction, paranormal, mystery/thriller, spiritual, horror, werewolves, fantasy, humour, young chick-lit, romance, classics, vampires, science fiction, adventure, teenage fiction, random, fanfiction, historical fiction, and nonfiction. The use of the wattpad platform makes it easy for students to access prose literature without limitations (Rahman, 2019). Thus is easy to use especially for reading a short story.

Meanwhile, the last question is "What did you do after reading a short story in Wattpad?" The student answered,

"Yes, I often give the author stars and followed them to know their recent stories or recent chapter. Also, we can communicate with them and other readers."

From the student's answer on the fifth question, the result showed that Wattpad gives a provide feature to know reader response. The users can also award "stars" (positive votes) to the works, follow each other's profiles and join thematic "clubs" (discussion forums) that focus on particular genres or other aspects of reading and writing (Tirocchi, 2018).

Deduced, the results of the interview from the first to the fifth questions had been analyzed and correlated with the theories in the second chapter at answering the third research question. The results showed that the experiences of EFL College Students' in enjoying short stories by means reading Wattpad.

Based on the students' answer, the result presented that the students' feel it easier and practical to read a short story because the students just open their mobile phone and didn't 
have to carry a book everywhere. According to Rahman (2019), Digital reading is reading the texts from the technological medium such as the cellphones, tablets, or computers either online or offline. Therefore, Wattpad is easier to access because Wattpad can support them to read short stories anywhere.

Also, Wattpad can increase their literacy and can help them to learn literature. In this case, Wattpad can help the students to learn about literature and can increase their literacy skill by reading a short story on Wattpad. Then, the students can have the same feeling with the story if the author can explaining or describing the situation well.

The students feel easy to find their favourite genre in Wattpad. Because Wattpad features a wide range of genres, including action, general fiction, paranormal, mystery/thriller, spiritual, horror, werewolves, fantasy, humour, young chick-lit, romance, classics, vampires, science fiction, adventure, teenage fiction, random, fan fiction, historical fiction, and nonfiction.

Therefore, is easy to use especially for reading a short story. Wattpad gives a provide feature to know reader response. The users can also award "stars" (positive votes) to the works, follow each other's profiles and join thematic "clubs" (discussion forums) that focus on particular genres or other aspects of reading and writing (Tirocchi, 2018).

\section{Discussion}

This section presents the discussion of this study. From the research findings How EFL College students enjoy short stories by using Wattpad and to see their responses to short stories and to find out how their perception and experiences in enjoying short stories by means reading Wattpad. They enjoyed reading Wattpad by giving two response interpretive/reflective response and affective response. According to Rahman (2019), Digital reading is reading the texts from the technological medium such as the cellphones, tablets, or computers either online or offline. Therefore, Wattpad is easier to access because can support them to read short stories anywhere. And Wattpad can increase their literacy and can help them to learn literature. It can be concluded that literary work like short story helps the student focused on the story content, plot and language components (Tevdovska, 2016). Wattpad can help the students to learn about literature and can increase their literacy skill by reading a short story on Wattpad.

The result of this research has a difference with the previous studies. Some previous studies had analyzed about Wattpad as a media to learning literature. However, the researcher tried to analyze the different purposes in identifying the data with the previous studies.

There are so many studies that use Wattpad as a media to learning literature. Rahman \& Iwan (2019) found that the Wattpad platform can be used to publish literary works students in the form of prose to further obtain constructive peer to peer feedback. Similar to Rahman and Iwan. (Sari, 2016) found that students were more interested in using the media and actively giving comments and express their feelings or ideas after reading the story. It means Wattpad can help students in learning literary. Then same as (Bal, 2018) argue that Wattpad was considered a venue where participants can express themselves comfortably.

Based on those previous studies, it can be concluded that there is the positive feedback of using Wattpad as a media to learning literature similar to those previous studies, this research also focuses on Wattpad as a media to learning literature. 


\section{Conclusions and Suggestions}

\section{Conclusions}

This study is to find out how EFL college students enjoy short stories by using Wattpad and to see their responses to short stories and to find out how their perception and experiences in enjoying short stories by means reading Wattpad.

Firstly, the conclusion how students enjoy reading a short story on Wattpad is a lot of students' could mention their personal beliefs that were brought back when they discussed some parts of the story and also they might reflect on their own experiences, attitudes, or knowledge it's called the interpretive response. Also, they can enable readers to empathically share feelings they have not experienced or experienced in their own lives. So affective response is an emotion that the students' feels when reading a short story it's called affective response

Secondly, the conclusion revealed to the questionnaire. It showed that the students gave a positive response toward a perception of the use of wattpad in reading short stories. They perceived Wattpad that is easier to read short stories and they can learn about new vocabulary by reading a short story on Wattpad. And a lot of students knows that they can improve their literacy skill by reading a short story on Wattpad. As a result, every student can access Wattpad anywhere and every time. So the students have easier access to learn new things and Wattpad is a useful media to help the students increase their literacy skill and vocabulary.

The last, the conclusion revealed that interview to the student. It can be concluded that the students' feel it easier and practical to read a short story because the students just open their mobile phone and didn't have to carry a book everywhere. Therefore, Wattpad is easier to access because Wattpad can support them to read short stories anywhere.

\section{Suggestion}

In this opportunity, the researcher would like to present some suggestions relate to using Wattpad to promote the students' responses to literary works: EFL College students' perspectives and experiences of enjoying short stories..

The first, after reading a short story the students are recommended to be more creative to respond to some short story. Furthermore, they are recommended to be able to create an imaginative story which is inspirited by their interesting different subject.

The second, for the next researcher, is recommended to explore other literary works like a novel, poetry, etc. as interest and motivation to improve literacy skill. Moreover, they also recommended being more objective to focus on one genre.

\section{References}

Al-mahrooqi, R. (2012). An investigation of literature teaching methodologies at a higher educational institution in Oman. TESOL Journal, 6(June), 172-180.

Bal, M. (2018). Reading and writing experiences of middle school students in the digital age: Wattpad sample. International Journal of Education \& Literacy Studies. Vol.6 No.2

Bold, M. R. (2018). The return of the social author: Negotiating authority and influence on Wattpad. Convergence: The International Journal of Research into New Media Technologies, 24(2), 117-136. DOI:10.1177/1354856516654459 
Coban, O. (2018). Reading choices and the effects of reading fiction: the responses of adolescent readers in Turkey to fiction and e-fiction. $\mathrm{PhD}$ thesis. Enlighten the Theses University of Gaslow. http://theses.gla.ac.uk/

Creswell, J.W. (2013). Qualitative Inquiry \& Research Design: Choosing Among Five Approaches. Thousand Oaks. California. SAGE Publications Inc.

Davies, Rosamund. (2017). Collaborative production and the transformation of publishing: The case of wattpad. In: Graham, J. and Gandini, A. (eds.). Collaborative Production in the Creative Industries, (pp. 51-67). London: University of Westminster Press. DOI: https://doi.org/10.16997/book4.d. License: CC-BY-NCND 4.0.

Febriani, R. B. Satinem., Nurnaningsih., Haryani., Syafryadin, Noermanzah.(2020). Conveying an author's intention to efl readers: The meaning of "The Road Not Taken" by Robert Frost. International Journal of Innovation, Creativity and Change (IJICC), 13(4), 172.

Gilakjani, A. P. (2017). 'A Review of the literature on the integration of technology into the learning and teaching of English language skills' International Journal of English Linguistics; 7(5); DOI:10.5539/ijel.v7n5p95

Handayani, S., Youlia, L., Febriani, R.B., Syafryadin, S. (2020). The use of digital literature in teaching reading narrative text. Journal Of English Teaching, Applied Linguistics And Literatures (JETALL). 3(2), 65-74.

Hansen, A. J. (2019). Short story: Literature' Retrieved from https://www.britannica.com/art/short-story

Iskhak. (2015). The application of reader-response theory in enhancing student teachers' affective and linguistic growth: A Classroom action research in EFL teacher education in Indonesia. The English Teacher, XLIV(2).

Kowalczyk, K. (2019). 7 best online destinations to read short stories for free. Retrieved from https://ebookfriendly.com/best-short-stories-read-online-free/

Luo, J., Boland, R., \& Chan, C. H. (2020). Roberts academic medicine handbook. In L. W. Roberts (Ed.), Roberts Academic Medicine Handbook (Second, p. 141). Springer. https://doi.org/10.1007/978-3-030-31957-1_1

Mart, C. T. (2019). Reader-response theory and literature discussions: A springboard for exploring literary texts. The New Educational Review 56(2). DOI: 10.15804/tner.2019.56.2.06

Ningrum, C. H. (2018). The use of reader-response theory to teach reading narrative text for tenth graders of senior high school. English Language Teaching, Language and Art Faculty, State University of Surabaya. Retrieved from: http://jurnalmahasiswa.unesa.ac.id

Nunning, V. (2017) The affective value of fiction presenting and evoking emotions. Ingeborg Jandl, Susanne Knaller, Sabine Schönfellner, Gudrun Tockner (eds.) Writing Emotions 
Theoretical Concepts and Selected Case Studies in Literature (pp. 29-54) Bielefeld: transcript. ISBN: 978-3-8376-3793-9

Rahman, I. A, Iwan (2019). Blending Wattpad platform and english prose course in industrial revolution era 4.0. English Language in Focus (ELIF), 2(1), 25-32

Reid, C. (2016) . Wattpad became a multiplatform entertainment venue Publishers Weekly, Retrieved from https://www.publishersweekly.com/pw/by-topic/digital/content-and-ebooks/article/72190-how-wattpad-became-a-multiplatform-entertainment-venue.html

Rebora, S., \& Pianzola, F. (2018). A new research programme for reading research: Analyzing comments in the margins on Wattpad. DigitCult -Scientific Journal on Digital Cultures, 3(2), 19-36. https://doi.org/10.4399/97888255181532

Sari, D. P (2016). The effects of short story through wattpad on reading comprehension achievement of non- English major students of Bina Darma University. Holistics Journal, 8. pp. 1-42. ISSN 2085-4021

Tevdovska, E. S. (2016). Literature in ELT Setting: Students' attitudes and preferences towards literary texts. Procedia - Social and Behavioral Sciences, 232, 161-169. https://doi.org/10.1016/j.sbspro.2016.10.041

Tirocchi, S. (2018). Wattpad. In C. A. Scolari (Ed.), Teen Media and Collaborative Culture (pp. 93-97). Barcelona: Universitat Pompeu Fabra

Yazan, B. (2015). Three approaches to case study methods in education: Yin, Merriam, and Stake. The Qualitative Report, 20(2), 134-152. from https://nsuworks.nova.edu/tqr/vol20/iss2/12 